\title{
INTENTION TO PURCHASE PRODUCTS UNDER VOLUME DISCOUNT SCHEME: A CONCEPTUAL MODEL AND RESEARCH PROPOSITIONS
}

\author{
Mohammad IRANMANESH ${ }^{1}$, Krishnaswamy JAYARAMAN $^{2}$, Ishak ISMAIL ${ }^{3}$ \\ ${ }^{1,3}$ School of Management, Universiti Sains Malaysia, 11800 USM, Penang \\ ${ }^{2}$ Graduate School of Business, Universiti Sains Malaysia, 11800 USM, Penang

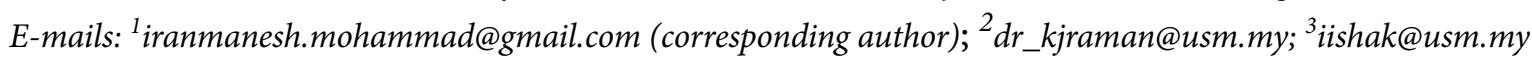

Received 09 February 2014; accepted 15 October 2014

\begin{abstract}
Many standard brands sell products under the volume discount scheme (VDS) as more and more consumers are fond of purchasing products under this scheme. Despite volume discount being commonly practiced, there is a dearth of research, both conceptual and empirical, focusing on purchase characteristics factors and consumer internal evaluation concerning the purchase of products under VDS. To attempt to fill this void, this article develops a conceptual model on VDS with the intention of delineating the influence of the purchase characteristics factors on the consumer intention to purchase products under VDS and provides an explanation of their effects through consumer internal evaluation. Finally, the authors discuss the managerial implications of their research and offer guidelines for future empirical research.
\end{abstract}

Keywords: volume discount scheme, consumer internal evaluation, purchase characteristics, purchase.

JEL Classification: M310.

\section{Introduction}

In marketing research, sales promotion (SP) plays a vital role not only for the benefits of consumers but also for the manufacturers to increase their volume of business, and, simultaneously, nurture new consumers of the products. A large proportion of the marketing budget is spent on sales promotion. However, most of the SP activities fail and are unable to fulfil the retailers' goals (Grewal et al. 1998), due to the retailers' lack of knowledge concerning different types of promotion and the appropriate conditions for use. The inappropriate application of sales promotions may lead to a reduction in the likelihood of a brand and product being chosen (Campo, Yague 2007). Therefore, the retailers are interested in finding possible ways to predict the effectiveness of selected SPs to increase consumer intention on purchasing decisions (Laroche 2002).

There are different types of SP available in the market. While the research on price discount has been extensive
(Neslin, Shoemaker 1989; Chang et al.2011) and the crucial dimensions of price discount in several contexts have been studied, the research on non-price promotions (volume discount) is very limited (Carpenter, Moore 2008). Under the volume discount scheme (VDS), the retailer or manufacturer rewards those purchasing in bulk or by unit by providing a reduced price for each product or group of products, e.g. $5 \%$ (or more) extra, buy one (or more) shirt(s) and get one (or more) free, buy one and get one with 50\% discount, and coupons that can be exchanged for an extra volume on repurchase. All over the world, the sales promotion under volume discount is commonly practiced as more and more consumers are becoming fond of purchasing products under volume discount. Jayaraman et al. (2013) showed that VDS is one of the most common sales promotion tactics at Business-to-Consumer (B-to-C) level in Malaysia.

A sales promotion that is effective for your competitors may not be effective for your brand or store and a promotion that works for a product, may not work for other products.

Copyright $\odot 2014$ The Authors. Published by VGTU Press.

This is an open-access article distributed under the terms of the Creative Commons Attribution-NonCommercial 4.0 (CC BY-NC 4.0) license, which permits unrestricted use, distribution, and reproduction in any medium, provided the original author and source are credited. The material cannot be used for commercial purposes.

To link to this article: http://dx.doi.org/10.3846/btp.2014.435 
Sinha and Smith (2000) found that volume discount is an effective way to promote storable products. However, contrary to Sinha and Smith (2000), Li et al. (2007) found that there is no relationship between the storability of products and the intention to purchase products under VDS. This is a real motivation for developing a conceptual framework to make it possible to test the direct and indirect relationship of factors (cause-effect) that influence VDS sales promotion.

From the consumers' point of view, SPs are more than just money-off. Raghubir and Corfman (1999) pointed out that consumers judge the quality of a product based on the depth of promotions. Further, Inman et al. (1990) and Raghubir (1998) remarked that, in general, SPs may mislead the consumers on the price image of the product as the product is sold at a lower price during the SP period. Therefore, it is essential to conceptualize the stimulus and situations that may create the real perception of quality and monetary savings when the product is promoted, especially under VDS.

\section{Background on general framework of sales promotion}

The majority of the research studies conducted before 2000 included the factor monetary savings while conceptualizing the framework, and claim that it is the only benefit of SP to the consumers (Chen et al. 1998). The asseverations of these studies raise a question: can monetary savings alone completely explain the consumer response behaviour to the SPs? If so, then everyday low price tactics should be successful in any store, brand, and on any products due to minimizing the search cost to the consumers. Nevertheless, previous studies have found that the everyday low price tactic cannot fully replace SP strategies (Hoch et al. 1994; Lal, Rao 1997). If not, what other consumer perceptions of the benefits of SPs affect consumer evaluation? Towards this, Chandon et al. (2000) proposed a research framework of the multiple consumer benefits of sale promotions. They categorized the benefits of SPs to the consumers as utilitarian benefits (savings, higher product quality, and improved shopping convenience) and hedonic benefits (value expression, entertainment, and exploration). They found that non-monetary promotions (free gift and sweepstake) provide more hedonic benefits and fewer utilitarian benefits than monetary promotions (price cut and free product). Therefore, they concluded that monetary promotions should be more effective for utilitarian products whereas non-monetary promotions should be more successful for hedonic products. Palazon and Delgado (2005) demonstrated that non-monetary promotion is also appropriate for utilitarian products as it generates empirical benefits.
Raghubir et al. (2004) extended the ideas of Chandon et al. (2000) and constructed an integrated SP model to assist marketers to design SP more efficiently as well as more effectively. The researchers considered additional utilitarian and hedonic benefits and explicitly address the informative effects of SP. In their research model SPs have three aspects; namely, economic, informational, and affective aspects. An economic aspect of SPs is that they generate monetary economic drivers and non-monetary drivers, such as make purchase decision cheaper, easier, and save searching time. Informational aspects refer to consumers' use of promotion as an informational tool to infer the quality and price of promoted products or as a reminder. The affective aspect of SP implies to the positive and negative consumers' feelings about their shopping deal. The findings reveal that the informative and effective aspects of SP offers are different and they can boost or diminish the attractiveness of the offer beyond the economic aspects of the SP.

The initial studies on sales promotions proposed by Chandon et al. (2000) and Raghubir et al. (2004) conceptualized the management models in general. Both models are related to sales promotions and do not focus on volume discount. In fact, the definitions and measurement of variables differ for different types of promotion as the nature of the promotions are different. Chandon et al. (2000) considered a reduction in search and purchase decision cost as relative factors of perceived convenience. In fact, these factors are more appropriate for price discount than VDS. Moreover, there are other factors like reduction in shopping trips and minimizing the time of purchasing through fewer trips that are not taken into account by Chandon et al. (2000), which are obviously essential to the study of VDS. Hence, it is necessary to have a special conceptual model for each sales promotion, and, accordingly, the present study concentrates on VDS. In addition, they did not consider the effect of situational factors in their models, which can affect consumer intention and their decision to purchase products under SPs. If situational factors, such as store type, brand type, and product category affect consumer intention to purchase products under VDS then a key managerial implication is that retailers get to know the expectations and needs of the consumers.

\section{Development of the research model}

The current study uses literature review and interview, to identify the factors that related to volume discount. Chandon et al. (2000) proposed six benefits of sales promotion that actuate the consumer to respond to sales promotion. However, there is no literature to indicate which of these six benefits are related to volume discount. Based on the structured personal interviews with 50 Malaysian consumers, the perceived savings, perceived quality, perceived 
self-expression value, and perceived convenience were found to be internal evaluation factors that Malaysian consumers consider when encountering volume discount schemes. The purchase characteristics of VDS (Independent variables) are explored through meta-analysis on perceived savings (Appendix I) and perceived quality (Appendix II). A second interview was conducted with 30 respondents who have experienced the purchase of products under VDS to select the most important variables for the purchase characteristics of VDS and to develop the measurement items for new constructs.

The initial conceptual framework was developed based on the literature review and interview. The conceptual framework, as presented in Figure 1, posits that the purchase characteristics of VDS like product category, brand image, store image, scheme characteristics, message framing, and subjective norms influence the consumer internal evaluation of benefits. The link between purchase characteristics of VDS and consumer internal evaluation of benefits is mediated by consumer internal evaluation of the benefits; namely, perceived savings, perceived quality, perceived self-expression value, and perceived convenience.

In order to enrich the research framework and to have new inputs, some experts in the Malaysian consumenr market (Business-to-Consumer) were interviewed. Since the literature on sales promotion particularly under volume discount scheme is not researched that much (Iranmanesh et al. 2013), the marketing expert views were helpful in validating the model variables and their relationships on the consumers' intention to purchase products under VDS. Towards this, eight interviews were conducted by supervisors and managers of major shopping malls of Malaysia which includes Tesco, Giant, AEON, AEON Big, Sunshine, and Cold Storage. The interviewees also confirmed the importance of considered variables and relationships in understanding consumers' response to VDS.
The links between variables are supported by the Stimulus-Organism-Response (S-O-R) model (Bagozzi 1986). The justification for using the $\mathrm{S}-\mathrm{O}-\mathrm{R}$ model in the present study is the relevant theoretical support extended to examine how marketing stimulus affect consumer intention to purchase products under VDS. The researchers (Mummalaneni 2005; Kim et al. 2009) have applied the S-O-R paradigm to predict consumer purchase behaviour and the findings supported its applicability. Secondly, the application of the S-O-R model has the strength of external stimulus and internal processes at the same time. The $\mathrm{S}-\mathrm{O}-\mathrm{R}$ model proposes a linear relationship between the three stages of environmental and social stimuli, which act as an external cause to the organism. This approach assumes that stimuli can affect an inactive and unprepared organism (Eysenck, Keane 2000). However, nowadays, most modern theorists assume that information processing is led by an active organism whose past experience influences not only the processing of such information but even what information is sought and received. The information processing is both stimulus driven and concept driven (Moital 2006). In the present study, the consumer's brand image, store image and subjective norms realized from the consumers' past experience are considered in addition to external stimulus, such as product category, message framing, and scheme characteristics. These variables are supported by the re-conceptualized S-O-R theory developed by Jacoby (2002) and remove the limitations of the S-O-R theory.

\section{Purchase characteristics of VDS and consumers' internal evaluation of VDS benefits}

Krishna et al. (2002) found in their study, less consistent, small and plausible deals, presence of regular price, deals in non-frequent discount stores, and deals on national brand yield higher perceived savings. They found that presenting a regular price as an external reference price reduces

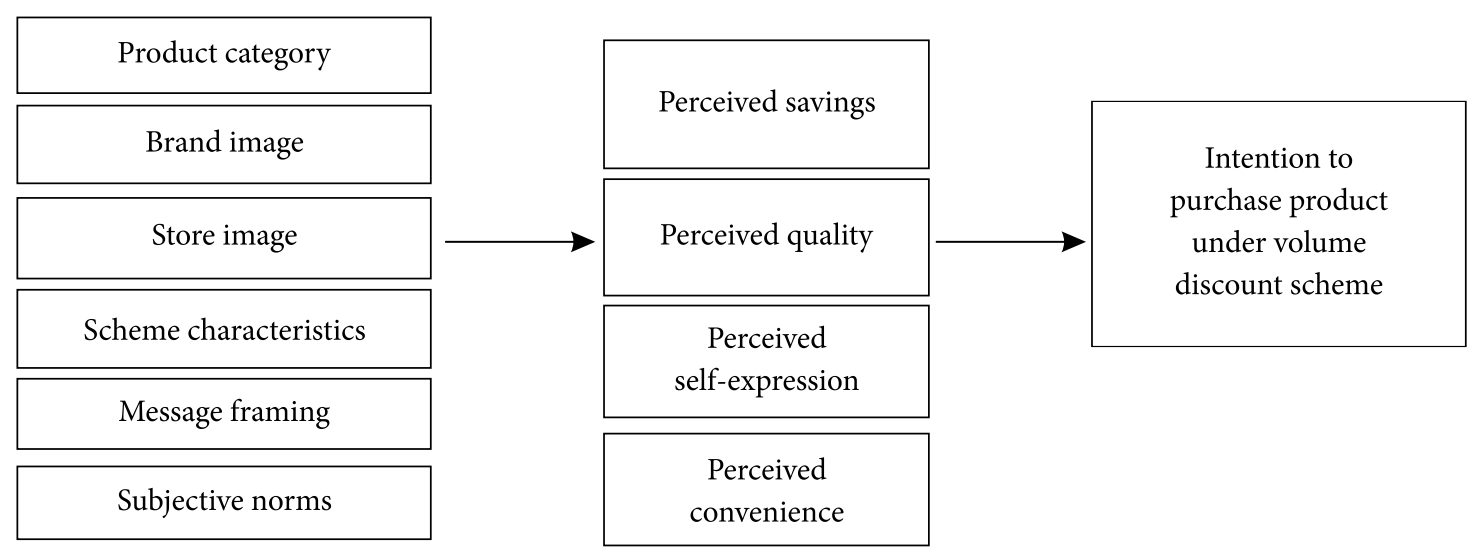

Fig.1. A volume discount scheme model 
perceived savings when the deal percentage is extremely large. Sinha and Smith (2000) found that the consumers perceived significantly higher transaction value from the extra-product promotion (buy one, get one free) than the mixed promotion (buy two, get $50 \%$ off). The reason that the "Buy two, get $50 \%$ off" deal is perceived so poorly visà-vis "Buy one, get one free" may be that the latter clearly signals a gain, while the former inherently implies a compulsion to purchase two units to receive the price reduction.

The previous studies on the factors influencing consumers' perceived quality of the products (Chang, Wildt 1994; Dodds et al. 1991), have focused on the product's extrinsic cues (e.g. price, brand, and advertising). Brand image is one of the strongest signals of the unobservable qualities of a product (Pascale et al. 2000; Severi, Ling 2013) and when consumers use prices as a cue for quality, they infer higher quality with higher prices (Olson 1977). On the other hand, Bitta et al. (1981) proposed that a strong brand helps to control or stabilize the perception of quality of a product even when its price is discounted. Dodds et al. (1991) also found empirical support for the positive effect of brand on the perception of quality. In addition to certain product-specific information, a cognitive relationship between consumers and products (i.e. image congruence) has been found to be a significant factor associated with consumer perception of a given product's quality (Graeff 1996; Pascale et al. 2000). For example, Graeff (1996) found that subjective product evaluation is a positive function of the degree of congruence between a consumer's self-image and the image of the product or retail outlet. Pascale et al. (2000) also found that product evaluation was a positive function of self-image congruence. Therefore, the more closely the consumer perceives the stereotype image of the product, the more likely they are to possess a favourable evaluative judgment of the product's quality. Bao et al. (2011) found that the store image is a diagnostic cue of store equity to consumers and allows them to infer the quality of merchandise.

Consumers tend to view themselves as responsible when they make a decision that results in a good outcome. This would suggest that smart-consumer feelings have important consequences for purchasing under SPs while those consumers who missed SPs will experience regret as a consequence. Berger and Heath (2007) found that brands allow consumers to perceive self-expression value. On the other hand, Tykocinski and Pittman (2001) found that consumers who have missed an opportunity to purchase a product at a significantly reduced price are less likely to purchase the product at a later time due to promotional pricing. Hence, factors like brand, store, necessary product, and deep sales promotion are expected to increase the perception of value in the minds of consumers and affect the self-expression value.
Sometimes consumers need to travel frequently to the shops due to the nature of products in terms of fast consuming and necessity. On the other hand, if the products are non-perishable and storable, they can purchase more at one time. Therefore, the product category has an effect on consumers' perception of convenience towards purchase under VDS.

Proposition 1: There are positive relationships between the purchase characteristics of VDS and the consumers' evaluation of VDS benefits.

\section{Consumer internal evaluation of VDS benefits and consumer intention to purchase products under VDS}

A number of studies have examined empirically the effect of perceived quality on purchase intention (Chang, Wildt 1994; Dodds et al. 1991; Tsiotsou 2006). Some studies have found an indirect relationship between perceived quality and purchase intention, which is mediated by perceived value (Chang, Wildt 1994; Dodds et al. 1991) and satisfaction (Tsiotsou 2006). In some studies, perceived quality has been found to have a positive direct effect on purchase intention (Parasuraman et al. 1996; Sheau-Fen et al. 2012). In addition, Chandon et al. (2000) proposed perceived savings, perceived quality, perceived self-expression value, and perceived convenience as the predictor of purchase intention.

Preposition 2: There are positive relationships between consumers' evaluation of VDS benefits and consumer intention to purchase products under VDS.

\section{Purchase characteristics of VDS and consumer intention to purchase products under VDS}

Favourable brand image has a positive effect on purchase intention (Eze et al. 2012; Madahi et al. 2012). In addition, Wu et al. (2011) found store image affects purchase intention directly. Scheme characteristics, such as restrictions, can signal the value of a deal to the consumers (Raghubir et al. 2004), which leads to purchase intention. Chen et al. (1998) stated that message framing affects consumer intention to purchase under SPs. The subjective norm appears to have a significant effect on consumers' behavioural intention (Chang et al. 1996; Cheung et al. 1999; Chiou 2000).

Proposition 3: There are positive relationships between the purchase characteristics of VDS and consumer intention to purchase products under VDS.

\section{Mediating effects of consumers internal evaluation of VDS benefits}

Consumers with positive beliefs about promotional offers have tended to respond positively to the deal due to the benefits they obtain from purchasing. Therefore, it is 
expected that the offer appropriate purchase characteristics of VDS will translate into better evaluations on VDS benefits, which lead to greater choice of promoted products. Bagozzi (1986) conceptualized that organisms mediate the relationship between stimulus and intention to purchase. There are many studies available in marketing (Kim et al. 2009; Lii, Sy 2009) that support the mediating role of the organism.

Proposition 4: Consumer internal evaluation of VDS benefits mediates the relationship between purchase characteristics and consumer intention to purchase products under VDS.

\section{Discussion}

There are many conceptual research frameworks available on SPs, in general (Chandon el al. 2000; Raghubir et al. 2004), while only a limited number of conceptualization studies have been undertaken on volume discount. Even in the limited number of studies on volume discounts, the researchers have not considered exhaustively all the potential purchase characteristics. Thus, a contribution of our work is to conceptualize a research framework to highlight the important purchase characteristics of consumers on VDS.

There are some conflicts in the findings of earlier researches on SPs as well as SPs on volume discount. For instance, Sinha and Smith (2000) found that there is a positive relationship between the storable characteristics of products and consumer intention to purchase on volume discount, whereas Li et al. (2007) found the contrary. These contradictory findings suggest that the general conclusions of prior research on important purchase characteristics of volume discount need to be researched further. The potential reasons for these conflicts may be the difference in the selected product categories, such as storability and necessary difference of the products or the difference in selected stores, such as low/high equity brand or difference in promotion characteristics, such as depth of promotion and deal frequency. The factors that affect consumer intention to purchase are interrelated, and, therefore, it is essential to consider all of them in one model and test them simultaneously. Our proposed model includes potential purchase characteristics together.

\section{Managerial implications}

The marketing research on promotional effectiveness is imperative at this juncture as SPs require a huge proportion of marketing expenditure (Kotler, Keller 2009). Therefore, retailers and manufacturers should identify the most suitable SP strategies based on product and situation specific to have the greatest positive impact on consumer purchase decision to gain the targeted profit. Although retailers have been using VDS as one of the SP strategies for so long, questions relating to the situational factors that affect consumer intention to purchase products under VDS remain unanswerable. If situational factors, such as store type, brand type, and product categories affect consumer intention to purchase products under VDS then a key managerial implication is that retailers must know the expectations and needs of the consumers. In the challenging marketing situation of the present day, the consumers' expectations are very high, and, therefore, the retailers and manufacturers may seriously consider the brand image, store image, and the quality of products that are promoted under VDS. At the same time, due to heavy competition on the market, the retailers and manufacturers must study the frequency of SP under VDS to be offered for a product, the display of products of VDS (VDS banner, Price tag, packaging), the extra quantity of a product, business ethics, the duration of the scheme, and appropriate time of inception while keeping in mind the competitors for that product. The current study offers a conceptual model to test the appropriate product categories to be sold under VDS, which will aid retailers and manufacturers.

Although the retailers and manufactures have knowledge on SPs through VDS, the pricing of the products and relative quality as per the consumers' perception are conceptualized in the present study. This will give the retailers and manufactures a better estimate of price and quality of the product to be promoted under VDS from the perspective of the consumers. The VDS has many benefits to the consumers, such as good deal to purchase a product, purchase before stocks finish, save time in shopping and reduction in number of shopping trips, provided the retailers and manufacturers adopt the correct measures of business tactics.

\section{Guideline for empirical testing in future}

\subsection{Measurement issues}

To empirically test our model, appropriate measures for the constructs in our framework must be developed and purified. Table 1 presents the various constructs used in our work and guidelines for their measurement. These measures are suggested as potential starting points for detailed empirical work in this area.

\subsection{Unit of analysis}

Individuals whose age is above 14 years and have experienced sales promotions under VDS during the last one year will be the unit of analysis. The restriction on age above 14 years is mainly due to the working age being from 15 years in most countries and needs to be modified based on the working rule of the country in which the experimental test of the proposed model will be conducted. 
Table 1. Variables, definitions, and illustrative measures

\begin{tabular}{|c|c|c|c|}
\hline Variable & Conceptual Definition & Measure Items & $\begin{array}{c}\text { Relevant } \\
\text { References }\end{array}$ \\
\hline $\begin{array}{l}\text { Product } \\
\text { Category }\end{array}$ & $\begin{array}{l}\text { Difference between products based } \\
\text { on product characteristics, namely, } \\
\text { storable / non storable, necessary / } \\
\text { non-necessary, fast / slow consuming, } \\
\text { perishable / non-perishable, mobility / } \\
\text { non-mobility products. }\end{array}$ & $\begin{array}{l}\text { Storable / Necessary / Fast consuming / Non-perishable / Mobility } \\
\text { items are suitable to have volume discounts. }\end{array}$ & $\begin{array}{l}\text { Sinha, Smith } \\
(2000) ; \mathrm{Li} \\
\text { et al. }(2007)\end{array}$ \\
\hline $\begin{array}{l}\text { Brand } \\
\text { Image }\end{array}$ & $\begin{array}{l}\text { Consumers' perception of the } \\
\text { favourite brands attributed to VDS } \\
\text { and to what extent consumers found } \\
\text { a particular brand favourite to them } \\
\text { from other brands. }\end{array}$ & $\begin{array}{l}\text { My favourite brands attract me with VDS products; my favourite } \\
\text { brands promote high quality merchandise under VDS; my } \\
\text { favourite brands promote reliable products under VDS; my } \\
\text { favourite brands promote superior products under VDS; the } \\
\text { products under VDS in my favourite brands are good value for } \\
\text { money; in my favourite brands the price of products under VDS } \\
\text { are reasonable; the VDS of my favourite brands are genuine. }\end{array}$ & $\begin{array}{l}\text { Grewal } \\
\text { et al. }(1998) ; \\
\text { Collins- } \\
\text { Dodd, } \\
\text { Lindley } \\
(2003)\end{array}$ \\
\hline Store Image & $\begin{array}{l}\text { Consumers' perception of the } \\
\text { favourite stores attributed to VDS and } \\
\text { to what extent consumers found a } \\
\text { particular store favourite to them from } \\
\text { other stores. }\end{array}$ & $\begin{array}{l}\text { My favourite stores attract me with VDS products; my favourite } \\
\text { stores provide special displays for VDS products; my favourite } \\
\text { stores promote high quality merchandise under VDS; the products } \\
\text { under VDS in my favourite stores are good value for money; in my } \\
\text { favourite stores the price of products under VDS are reasonable; } \\
\text { the VDS in my favourite stores are genuine. }\end{array}$ & $\begin{array}{l}\text { Grewal } \\
\text { et al. }(1998) \text {; } \\
\text { Collins- } \\
\text { Dodd, } \\
\text { Lindley } \\
(2003)\end{array}$ \\
\hline $\begin{array}{l}\text { Scheme } \\
\text { Charac- } \\
\text { teristics }\end{array}$ & $\begin{array}{l}\text { Scheme characteristics refer to the } \\
\text { issues concerning ethical, expiry date, } \\
\text { frequency, timing of promotion, and } \\
\text { depth of volume discount. }\end{array}$ & $\begin{array}{l}\text { Attracted towards the depth of volume discount / volume discount } \\
\text { with number of items restriction / the products sold under VDS } \\
\text { not close to expiry date / the products sold under VDS are not } \\
\text { defective / ethical VDS; time restricted / less frequent volume } \\
\text { discount promotion is preferable. }\end{array}$ & $\begin{array}{l}\text { Bitta et al. } \\
(1981) ; \\
\text { Inman } \text { et al. } \\
(1997) ; \\
\text { Raghubir } \\
\text { et al. }(2004)\end{array}$ \\
\hline $\begin{array}{l}\text { Message } \\
\text { Framing }\end{array}$ & $\begin{array}{l}\text { Message framing refers to consumer } \\
\text { guide to help them to have knowledge } \\
\text { on price label of VDS products, its } \\
\text { location of display in the stores and } \\
\text { some form of instruction. }\end{array}$ & $\begin{array}{l}\text { Attracted towards the display of amount of savings / percent of } \\
\text { savings through volume discount on price label; attracted towards } \\
\text { the display of old and new price after volume discount on price } \\
\text { label / towards attractive label of products sold under VDS; VDS } \\
\text { products display on "front-of-the-store"; "until stock finishes" } \\
\text { banner for VDS products. }\end{array}$ & $\begin{array}{l}\text { Gendall et al. } \\
(2006)\end{array}$ \\
\hline $\begin{array}{l}\text { Subjective } \\
\text { Norms }\end{array}$ & $\begin{array}{l}\text { The influence of friends, relatives, } \\
\text { colleagues, and store employees } \\
\text { accompanying the respondents while } \\
\text { purchasing products under VDS. }\end{array}$ & $\begin{array}{l}\text { Believe that, close associated / people around me / store employees } \\
\text { will not object if I purchase products under VDS. }\end{array}$ & $\begin{array}{l}\text { Self- } \\
\text { constructed }\end{array}$ \\
\hline $\begin{array}{l}\text { Perceived } \\
\text { Saving }\end{array}$ & $\begin{array}{l}\text { The consumer perception of monetary } \\
\text { savings during the purchase of VDS } \\
\text { products. }\end{array}$ & $\begin{array}{l}\text { Give importance to savings when purchased under VDS; when } \\
\text { purchase a product under VDS, get a good deal; terms under } \\
\text { VDS are really less expensive; with VDS, I am saving Money; the } \\
\text { product under VDS seems to be a bargain; in VDS, the price of } \\
\text { each item is less than what I expected it to be; in VDS, the price of } \\
\text { each item is less than the average market price. }\end{array}$ & $\begin{array}{l}\text { Grewal } \\
\text { et al. }(1998) \text {; } \\
\text { Parguel } \text { et al. } \\
(2007)\end{array}$ \\
\hline $\begin{array}{l}\text { Perceived } \\
\text { Quality }\end{array}$ & $\begin{array}{l}\text { The consumers' judgment on } \\
\text { promoted products under volume } \\
\text { discount on the overall excellence or } \\
\text { superiority of quality. }\end{array}$ & $\begin{array}{l}\text { Give importance to quality when purchasing under VDS; satisfied } \\
\text { with the quality of the product bought under VDS; the products } \\
\text { which are sold under VDS are of high quality / very reliable / } \\
\text { superior products }\end{array}$ & $\begin{array}{l}\text { Parasuraman } \\
\text { et al. }(1996) ; \\
\text { Grewal } \text { et al. } \\
(1998)\end{array}$ \\
\hline $\begin{array}{l}\text { Perceived } \\
\text { Self-Expres- } \\
\text { sion Value }\end{array}$ & $\begin{array}{l}\text { The consumers' self-perception of } \\
\text { smartness may turn to disappointment } \\
\text { or regret if the purchase of products } \\
\text { under VDS yields loss. }\end{array}$ & $\begin{array}{l}\text { If product purchased under VDS, have pleasure of having done a } \\
\text { good deal; will be happy to have taken advantage of VDS offer; feel } \\
\text { smart / feel lucky to purchase specially products under VDS; feel } \\
\text { regret if miss out the VDS. }\end{array}$ & $\begin{array}{l}\text { Parguel } \\
\text { et al. }(2007) \text {; } \\
\text { Raghubir } \\
\text { et al. }(2004)\end{array}$ \\
\hline $\begin{array}{l}\text { Perceived } \\
\text { Conve- } \\
\text { nience }\end{array}$ & $\begin{array}{l}\text { The consumers' perception of } \\
\text { convenience to purchase products } \\
\text { under VDS. }\end{array}$ & $\begin{array}{l}\text { VDS makes shopping fast / easy; VDS reduces the number of trips } \\
\text { to shop; feel more comfortable to purchase more in one purchase. }\end{array}$ & $\begin{array}{l}\text { Chandon } \\
\text { et al. }(2000) \text {; } \\
\text { To et al. } \\
(2007)\end{array}$ \\
\hline $\begin{array}{l}\text { Intention } \\
\text { to purchase } \\
\text { product un- } \\
\text { der volume } \\
\text { discount } \\
\text { scheme }\end{array}$ & $\begin{array}{l}\text { The consumers' intention on the } \\
\text { probability of purchase decision under } \\
\text { VDS. }\end{array}$ & $\begin{array}{l}\text { Willingness to purchase under VDS is very high; the probability } \\
\text { that purchase under VDS is very high; intend to purchase products } \\
\text { under VDS when it is offered; expect to purchase products under } \\
\text { VDS when it is offered; will recommend others to purchase special } \\
\text { products under VDS. }\end{array}$ & $\begin{array}{l}\text { Grewal } \\
\text { et al. (1998); } \\
\text { Jayaraman } \\
\text { et al. }(2012)\end{array}$ \\
\hline
\end{tabular}




\subsection{Statistical data analysis}

To fulfil the main objectives of the research, partial least squares (PLS-SEM) is appropriate since it is suitable for identifying the key driver constructs and the structural model, which is complex (Hair et al. 2011). However, the PLS-SEM is suggested for testing the proposed model as both the theoretical knowledge and substantive knowledge on volume discount is limited.

\section{Conclusions}

Volume discount is one of the attractive promotion strategy among Asian pacific consumers and is commonly prevalent in the market. In the present study, an attempt is made to investigate the situation in which volume discount warrants for in the consumer points of view. In this context, a business model is proposed to study the determinants of volume discount in the form of product category, brand image, store image, message framing, scheme characteristics, and subjective norms. Further, the ultimate benefits of volume discount through perceived savings, perceived quality, perceived self-expression and perceived convenience on the predictor variables and the purchase intention on volume discounts are enlightened.

\section{References}

Bagozzi, R. P. 1986. Principles of marketing management. Science Research Associates Inc., Chicago.

Bao, Yo.; Bao, Ye.; Shen, S. 2011. Motivating purchase of private brands: effects of store image, product signatureness, and quality variation, Journal of Business Research 64(2): 220-226. http://dx.doi.org/10.1016/j.jbusres.2010.02.007

Berger, J.; Heath, C. 2007. Where consumers diverge from others: identity signaling and product domains, Journal of Consumer Research 34(2): 121-134.

http://dx.doi.org/10.1086/519142

Bitta, A. J. D.; Monroe, K. B.; McGinnis, J. M. 1981. Consumer perceptions of comparative price advertisements, Journal of Marketing Research 18(4): 416-427. http://dx.doi.org/10.2307/3151334

Campo, S.; Yague, M. J. 2007. The perception of price discounts according to consumer's characteristics, Journal of Revenue and Pricing Management 6: 86-99.

http://dx.doi.org/10.1057/palgrave.rpm.5160068

Carpenter, J. M.; Moore, M. 2008. US consumers' perceptions of non-price retail promotions, International Journal of Retail \& Distribution Management 36(2): 111-123. http://dx.doi.org/10.1108/09590550810853066

Chandon, P.; Wansink, B.; Laurent, G. 2000. A benefit congruency framework of sales promotion effectiveness, Journal of Marketing 64(4): 65-81.

http://dx.doi.org/10.1509/jmkg.64.4.65.18071

Chang, H. J.; Lin, W. F.; Ho, J. F. 2011. Closed-form solutions for Wee's and Martin's EOQ models with a temporary price discount, International Journal of Production
Economics 131(2): 528-534.

http://dx.doi.org/10.1016/j.ijpe.2011.01.021

Chang, T. Z.; Wildt, A. R. 1994. Price, product information, and purchase intention: an empirical study, Journal of the Academy of Marketing Science 22(1): 16-27. http://dx.doi.org/10.1177/0092070394221002

Chang, Y.; Burns, L. D.; Noel, C. J. 1996. Attitudinal versus normative influence in the purchase of brand-name casual apparel, Family and Consumer Sciences Research Journal 25: 79-109. http://dx.doi.org/10.1177/1077727X960251004

Chen, S.; Monroe, K.; Lou, Y. 1998. The effects of framing price promotion messages on consumers' perceptions and purchase intentions, Journal of Retailing 74(3): 353-372. http://dx.doi.org/10.1016/S0022-4359(99)80100-6

Cheung, S. F.; Chan, D. K. S.; Wong, Z. S. Y. 1999. Reexamining the theory of planned behaviour in understanding wastepaper recycling, Environment and Behaviour 31: 587-612. http://dx.doi.org/10.1177/00139169921972254

Chiou, J. 2000. Antecedents and moderators of behavioural intention: differences between U.S. and Taiwanese students, Genetic, Social, and General Psychology Monographs 126: 105-124.

Collins-Dodd, C.; Lindley, T. 2003. Store brand and retail differentiation: the influence of store image and store brand attitude on store own brand perceptions, Journal of Retailing and Consumer Services 10: 345-352. http://dx.doi.org/10.1016/S0969-6989(02)00054-1

Das, P. 1992. Semantic cues and buyer evaluation of promotional communication, in R. Leone, V. Kumar (Eds.). AMA Educator's Proceedings: Enhancing Knowledge Development in Marketing, 1992, American Marketing Association, Chicago, IL, 12-17.

Dodds, W. B.; Mornoe, K. B.; Grewal, D. 1991. Effects of price, brand and store information on buyers' product evaluations, Journal of Marketing Research 28(3): 307-319. http://dx.doi.org/10.2307/3172866

Eysenck, M. W.; Keane, M. T. 2000. Cognitive psychology: a student's handbook. 4th ed. London: Lawrence Erlbaum.

Eze, U. C.; Tan, C. B.; Yeo, A. L. Y. 2012. Purchasing cosmetic products: a preliminary perspective of Gen-Y, Contemporary Management Research 8(1): 51-60.

Gendall, P.; Hoek, J.; Pope, T.; Young, K. 2006. Message framing effects on price discounting, Journal of Product and Brand Management 15(7): 458-465. http://dx.doi.org/10.1108/10610420610712847

Graeff, T. R. 1996. Image congruence effects on product evaluations: the role of self-monitoring and public/private consumption, Psychology and Marketing 13(5): 481-499. http:// dx.doi.org/10.1002/(SICI)1520-6793(199608)13:5<481::AIDMAR3 $>3.0 . C O ; 2-5$

Grewal, D.; Krishnan, R.; Baker, J.; Borin, N. 1998. The effect of store name, brand name, and price discounts on consumers' evaluations and purchase intentions, Journal of Retailing 74(3): 331-352. http://dx.doi.org/10.1016/S0022-4359(99)80099-2

Hair, J. F.; Ringle, C. M.; Sarstedt, M. 2011. PLS-SEM: indeed a silver bullet, Journal of Marketing Theory and Practice 19(2): 139-152. http://dx.doi.org/10.2753/MTP1069-6679190202 
Hoch, S. J.; Drèze, X.; Purk, M. 1994. EDLP, HiLo, and margin arithmetic, Journal of Marketing 58(4): 16-27. http://dx.doi.org/10.2307/1251913

Inman, J. J.; McAlister, L.; Hoyer, W. D. 1990. Promotion signal: proxy for a price cut?, Journal of Consumer Research 17: 74-81. http://dx.doi.org/10.1086/208538

Inman, J. J.; Peter, A. C.; Raghubir, P. 1997. Framing the deal: the role of restrictions in accentuating the deal value, Journal of Consumer Research 24: 68-79. http://dx.doi.org/10.1086/209494

Iranmanesh, M.; Jayaraman, K.; Jamaludin, R.; Taghizadeh, S. K. 2013. A business model of purchase stimulus on the consumer intention to buy products under volume discount through consumer behavior factors, Australian Journal of Basic and Applied Sciences 7(7): 874-882.

Jacoby, J. 2002. Stimulus-organism-response reconsidered: an evolutionary step in modeling (consumer) behaviour, Journal of Consumer Psychology 12(1): 51-57. http://dx.doi.org/10.1207/S15327663JCP1201_05

Jayaraman, K.; Iranmanesh, M.; Kaur, M. D.; Haron, H. 2013. Consumer reflections on "Buy One Get One Free" (BOGO) promotion scheme - an empirical study in Malaysia, Research Journal of Applied Sciences, Engineering and Technology 5(9): 2740-2747.

Jayaraman, K.; Iranmanesh, M.; Foon, L. C.; Lin, S. K. 2012. Factors influencing intention/continuance to use smart card e-payment in public transportation - age as a moderator, Archives Des Sciences 65(8): 552-556.

Kim, J. E.; Ju, H. W.; Johnson, K. K. P. 2009. Sales associate's appearance: links to consumers' emotions, store image, and purchases, Journal of Retailing and Consumer Services 16: 407-413. http://dx.doi.org/10.1016/j.jretconser.2009.06.001

Kotler, P.; Keller, K. L. 2009. Marketing management. 13th ed. Upper Saddle River, NJ: Prentice Hall.

Krishna, A.; Briesch, R.; Lehman, D. R.; Yuan, H. 2002. A meta-analysis of the impact of price presentation on perceived savings, Journal of Retailing 78: 101-118. http://dx.doi.org/10.1016/S0022-4359(02)00072-6

Kumar, A. M.; Lee, H. J.; Kim, Y. K. 2009. Indian consumers; purchase intention toward a united States versus local brand, Journal of Business Research 62(5): 521-527. http://dx.doi.org/10.1016/j.jbusres.2008.06.018

Lal, R.; Rao, R. 1997. Supermarket competition: the case of everyday low pricing, Marketing Science 16(1); 60-80. http://dx.doi.org/10.1287/mksc.16.1.60

Laroche, M. 2002. Selected issues in modeling consumer brand choice: the extended competitive vulnerability model, advances in marketing theory and practice. New York, NY: JAI Press, 69-114.

Li, S.; Sun, Y.; Wang, Y. 2007. 50\% off or buy one get one free? Frame preference as a function of consumable nature in dairy product, The Journal of Social Psychology 147(4): 413-421. http://dx.doi.org/10.3200/SOCP.147.4.413-422

Lii, Y. S.; Sy, E. 2009. Internet differential pricing: effects on consumer price perception, emotions, and behavioural responses, Computers in Human Behaviour 25: 770-777. http://dx.doi.org/10.1016/j.chb.2009.02.005

Madahi, A.; Sukati, I.; Mazhari, M. Y.; Rashid, W. N. 2012. Consumer decision making styles amongst young generation in Malaysia, European Journal of Social Sciences 30(2): 263-275.

Moital, M. L. 2006. An evaluation of the factors influencing the adoption of e-commerce in the purchasing of leisure travel by the residents of Cascais, Portugal: Doctoral dissertation. Bournemouth University, UK.

Mummalaneni, V. 2005. An empirical investigation of Web site characteristics, consumer emotional states and online shopping behaviours, Journal of Business Research 58: 526-532. http://dx.doi.org/10.1016/S0148-2963(03)00143-7

Neslin, S. A.; Shoemaker, R. W. 1989. An alternative explanation for lower repeat rates after promotion purchases, Journal of Marketing Research 26: 205-213.

http://dx.doi.org/10.2307/3172606

Olson, J. C. 1977. Price as an informational cue: ects in product evaluation, in A. G. Woodside, J. N. Sheth, P. D. Bennet. Consumer and industrial buying behaviour. New York: North-Holland Publishers, 267-286.

Palazon, V. M.; Delgado, B. E. 2005. Sales promotions effects on consumer based brand equity, International Journal of Market Research 47(2): 179-204.

Parasuraman, A.; Zeithaml, V.; Berry, L. 1996. The behavioural consequences of service quality, Journal of Marketing 60: 31-46. http://dx.doi.org/10.2307/1251929

Parguel, B.; Pechpeyrou, P. D.; Sabri-Zaaraoui, O.; Demset, P. 2007. Format effects in volume discounts to consumers, Journal of Product and Brand Management 16(5): 348-357. http://dx.doi.org/10.1108/10610420710779645

Pascale, G. Q.; Amal, K.; Li, K. G. 2000. Self-congruity and product evaluation: a cross-cultural study, Journal of Consumer Marketing 17(6): 525-537. http://dx.doi.org/10.1108/07363760010349939

Raghubir, P. 1998. Coupon value: a signal for price, Journal of Marketing Research 35: 316-324. http://dx.doi.org/10.2307/3152030

Raghubir, P.; Corfman, K. P. 1999. When do price promotions affect brand evaluations?, Journal of Marketing Research 36(2): 211-222. http://dx.doi.org/10.2307/3152094

Raghubir, P.; Inman, J. J.; Grande, H. 2004. The three faces of consumer promotions, California Management Review 46(4): 23-42. http://dx.doi.org/10.2307/41166273

Salganik, M. J.; Dodds, P. S.; Watts, D. J. 2006. Experimental study of inequality and unpredictability in an artificial cultural market, Science 311(5762): 854-856. http://dx.doi.org/10.1126/science.1121066

Severi, E.; Ling, K. C. 2013. The mediating effect of brand association, brand loyalty, brand image and perceived quality on brand equity, Asian Social Science 9(3): 125-137. http://dx.doi.org/10.5539/ass.v9n3p125

Sheau-Fen, Y.; Sun-May, L.; Yu-Ghee, W. 2012. Store brand proneness: effects of perceived risks, quality and familiarity, Australasian Marketing Journal 20: 48-58. http://dx.doi.org/10.1016/j.ausmj.2011.10.014

Sinha, I.; Smith, M. F. 2000. Consumers' perceptions of promotional framing price, Psychology and marketing 17(3): 257-275. http://dx.doi.org/10.1002/(SICI)15206793(200003)17:3<257::AID-MAR4>3.0.CO;2-P 
To, P. L.; Liao, C.; Lin, T. H. 2007. Shopping motivations on Internet: a study based on utilitarian and hedonic value, Technovation 27(12): 774-788.

http://dx.doi.org/10.1016/j.technovation.2007.01.001

Tsiotsou, R. 2006. The role of perceived product quality and overall satisfaction on purchase intentions, International Journal of Consumer Studies 2: 207-217. http://dx.doi.org/10.1111/j.1470-6431.2005.00477.x

Tykocinski, O. E.; Pittman, T. S. 2001. Product aversion following a missed opportunity: price contrast or avoidance of anticipated regret?, Basic and Applied Social Psychology 23(3): 149-156. http://dx.doi.org/10.1207/S15324834BASP2303_1

Wang, S. M.; Lin, J. C. C. 2011. The effect of social influence on bloggers' usage intention, Online Information Review 35(1): 50-65. http://dx.doi.org/10.1108/14684521111113588
Wu, P. C. S.; Yeh, G. Y. Y.; Hsiao, C. R. 2011. The effect of store image and service quality on brand image and purchase intention for private label brands, Australian Marketing Journal 19(1):30-39. http://dx.doi.org/10.1016/j.ausmj.2010.11.001

Yoo, B.; Donthu, N.; Lee, S. 2008. An examination of selected marketing mix elements and brand equity, Journal of the Academy of Marketing Science 28(2): 195-211. http://dx.doi.org/10.1177/0092070300282002

Zeithaml, V. A. 1988. Consumer perceptions of price, quality, and value: a means-end model and synthesis of evidence, Journal of Marketing 52(2): 2-22. http://dx.doi.org/10.2307/1251446 


\section{APPENDIX I}

\section{Literature on perceived savings}

\begin{tabular}{|l|l|l|}
\hline \multicolumn{1}{|c|}{ Study variables } & \multicolumn{1}{|c|}{ Effects on perceived savings } & \multicolumn{1}{|c|}{ Source of literature } \\
\hline Amount of Deal, Percent of Deal & Positively influencing perceived savings & $\begin{array}{l}\text { Krishna } \text { et al. (2002); Raghubir } \text { et al. } \\
\text { (2004) }\end{array}$ \\
\hline Regular Price & $\begin{array}{l}\text { Offering regular price increases } \\
\text { perceived savings }\end{array}$ & $\begin{array}{l}\text { Krishna } \text { et al. (2002); Dodds } \text { et al. (1991); } \\
\text { Zeithaml (1988) }\end{array}$ \\
\hline Number of items on deal & $\begin{array}{l}\text { Less number of items on deal increases } \\
\text { perceived savings }\end{array}$ & Krishna et al. (2002) \\
\hline Variance of Deals & $\begin{array}{l}\text { High deal variances lead to lower } \\
\text { perceived savings }\end{array}$ & Krishna et al. (2002) \\
\hline Deal frequency & $\begin{array}{l}\text { The greater the frequency of price } \\
\text { promotions leads to lower perceived } \\
\text { savings }\end{array}$ & Raghubir et al. (2004) \\
\hline Deal regularity & $\begin{array}{l}\text { The greater the deal regularity lead to } \\
\text { lower perceived savings }\end{array}$ & Raghubir et al. (2004) \\
\hline $\begin{array}{l}\text { Brand Type: National Brands vs. } \\
\text { Private Brands and Generics }\end{array}$ & $\begin{array}{l}\text { National Brands yield higher perceived } \\
\text { savings }\end{array}$ & Krishna et al. (2002); Dodds et al. (1991) \\
\hline $\begin{array}{l}\text { Type of Good: Packaged Goods vs. } \\
\text { Other (durable, soft) Goods }\end{array}$ & $\begin{array}{l}\text { Packaged Goods yield higher perceived } \\
\text { savings }\end{array}$ & Krishna et al. (2002); Das (1992) \\
\hline $\begin{array}{l}\text { Store Type: Discount Store vs. } \\
\text { Department and Specialty Stores }\end{array}$ & $\begin{array}{l}\text { Discount Stores lead to lower perceived } \\
\text { savings }\end{array}$ & Krishna et al. (2002); Dodds et al. (1991) \\
\hline Amount of information & $\begin{array}{l}\text { The display of a reference price } \\
\text { increases perceived savings }\end{array}$ & Raghubir et al. (2004) \\
\hline Restriction & $\begin{array}{l}\text { Consumers believe that the retailer } \\
\text { restricts the quantity of purchase as they } \\
\text { lose many potential customers }\end{array}$ & Inman et al. (1997) \\
\hline
\end{tabular}

\section{APPENDIX II}

\section{Literature on perceived quality}

\begin{tabular}{|l|l|}
\hline \multicolumn{1}{|c|}{ Study variables } & \multicolumn{1}{c|}{ Source of literature } \\
\hline Price & Yoo et al. (2008); Grewal et al. (1998) \\
\hline Brand image & Dodds et al. (1991); Pascale et al. (2000); Severi, Ling (2013) \\
\hline Store Image & Dodds et al. (1991); Yoo et al. (2008); Grewal et al. (1998); Pascale et al. (2000) \\
\hline Country of Origin & Raghubir et al. (2004); Kumar et al. (2009) \\
\hline Spent on Advertisements & Yoo et al. (2008) \\
\hline Frequency of deal & Yoo et al. (2008) \\
\hline Subjective Norms & Salganik et al. (2006); Wang, Lin (2011) \\
\hline
\end{tabular}

Mohammad IRANMANESH. PhD candidate of Marketing. School of Management, University Sains Malaysia. Research Interest: Service Marketing, Sales Promotion, and Branding.

Krishnaswamy JAYARAMAN. Associate Professor. Graduate School of Business, University Sains Malaysia. Research Interest: Research Methods, Service Quality Management, Marketing, and Tourism.

Ishak ISMAIL. Professor of Marketing. School of Management, University Sains Malaysia. Research Interest: Service Marketing/ Management, Entrepreneurship, Business Ethics, and Corporate Governance. 